\title{
Ecosystem Services in the Service-Dominant Logic Framework.
}

\section{Caputo, Jesse}

Springer

2019

Caputo , J , D'amato , D \& Matthies , B D 2019 , Ecosystem Services in the Service-Dominant Logic Framework. in T Hujala , A Toppinen \& B Butler (eds), Services in

Family Forestry . World Forests , vol. 24 , Springer , pp. 21-47 . https://doi.org/10.1007/978-3-030-28999-7_2

http://hdl.handle.net/10138/336069

https://doi.org/10.1007/978-3-030-28999-7_2

acceptedVersion

Downloaded from Helda, University of Helsinki institutional repository.

This is an electronic reprint of the original article.

This reprint may differ from the original in pagination and typographic detail.

Please cite the original version. 


\title{
Ecosystem Services in the Service-Dominant Logic (SDL) Framework
}

\author{
Jesse Caputo $^{1} \quad{ }^{2}$, and Brent D. Matthies ${ }^{2,3}$
}

\begin{abstract}
The ecosystem services concept has become the predominant lens through which researchers and decision-makers view the relationship between natural ecosystems and human well-being. Over the past decades, a number of widely-accepted classification systems, analytical methods, and a rich vocabulary around ecosystem services have evolved in the literature. Although there is widespread recognition that many ecosystem services are not exchanged in markets as commodities, many of these ecosystem service concepts and tools were built upon a theoretical foundation derived from neoclassical economics in which ecosystems are seen as passive production systems. Unfortunately, this perspective carries the potential to blind one to the complex interactions by which ecosystems, beneficiaries, and myriad other social actors interact to manage ecosystems and create human value. The service-dominant logic (SDL) framework, which views all value as being co-created by multiple actors engaged in the exchange of service, offers a valuable perspective by which the ecosystem services concept may be recast. Similarly, the ecosystem services lexicon can make important contributions to SDL by providing a means to describe and quantify the universal importance of natural ecosystems to human service systems. In this chapter, we briefly describe the ecosystem service concept and introduce the means for incorporating ecosystem services (as potential service offerings) into the SDL framework. We then use this modified framework to explore two case studies, recreation on U.S. family forests and a biodiversity market in Finland.
\end{abstract}

\section{Ecosystem services: concept and applications}

It is no novel idea that the natural world provides food, building materials, and other critical resources to human economies; in fact, the dependence of people on ecosystems has been an accepted fact for as long as people have been pondering the human condition. Nonetheless, there is increasing recognition in both the ecological literature and in the public dialogue of the ubiquitous role that natural systems play in supporting the lives and wellbeing of people across the globe. Ecosystem services, a broad term here referring to the benefits provided by natural systems to human populations, has become a perspective of significant interest for sustainability studies (Folke et al. 2016, Schröter et al. 2017).

There are several different definitions of ecosystem services. The various definitions coined for the term ecosystem services imply a different emphasis of the concept on the ecological or human dimensions (Fisher et al. 2009). There are also significant semantic differences. Some definitions equate ecosystem

\footnotetext{
${ }^{1}$ Family Forest Research Center, University of Massachusetts Amherst Department of Environmental Conservation

160 Holdsworth Way, Amherst, MA 01002 jessecaputo@eco.umass.edu

${ }^{2}$ Helsinki Institute of Sustainability Science

Faculty of Agriculture and Forestry, Department of Forest Sciences

Latokaartanonkaari 7, 00014 Helsinki, Finland

dalia.damato@helsinki.fi

${ }^{3}$ Dasos Capital

Itämerentori 2, Fl-00180 Helsinki, Finland

brent.matthies@dasos.fi
} 
services with ecological functions or socio-economic benefits (MEA 2005), whereas others tend to emphasize the distinction between these (Fisher et al. 2009). Researchers working with a natural science perspective most often treat ecosystem services as emergent and complex phenomena stemming from natural systems (e.g. Haines-Young and Potschin 2010, La Notte et al. 2017), whereas scholars involved with ecosystem services accounting treat them as end products - in other words as things such as plants, animals, or geological features (Boyd and Banzhaf 2007). Despite these differences, all definitions have in common the emphasis on ecosystems as sources of well-being for people. For the purpose of this section,

of ecosystems utilized (actively or passively) to produce human welldefinition in Section 2.

The Millennium Ecosystem Assessment (2005) provided the first and perhaps most widely-recognized and general classification system of ecosystem services. It categorized ecosystem services as provisioning (e.g. food, fibres, clean water, genetic resources), regulating (e.g. water, soil and nutrient cycle control, climate regulation, pest and diseases control) or cultural (e.g. nature-related tourism and recreation, aesthetic, spiritual and identity values) services. A fourth category, supporting services, underpin the previous three categories through maintenance of essential ecological functioning ${ }^{4}$. Other ecosystem services classifications have been proposed by The Economics of Ecosystems and Biodiversity (TEEB 2010), by the UK National Ecosystem Assessment (Davies et al. 2011), by the European Environmental Agency (the Common International Classification of Ecosystem Services - CICES) (Haines-Young and Potschin 2013), by the US Environmental Protection Agency (Final Ecosystem Goods and Services Classification System - FEGS-CS) (Landers and Nahlik 2013) and by the Intergovernmental Science-Policy Platform on Biodiversity and Ecosystem Services (Díaz et al. 2015). These can be broadly considered as complementary classification systems that provide different perspectives and instruments to operationalise ecosystem services research and decision-making. For instance, while CICES emphasises the role of ecological systems, the classification by the FEGS-CS is specifically designed to evaluate benefits and beneficiaries in the socio-economic system. Additional classification systems have been proposed for specific purposes, such as for example ecological accounting systems (Boyd and Banzhaf 2007, Wallace 2007). There is no single best classification system; a diversity of typologies serves different purposes and adds richness to the dialogue (Costanza 2008).

The cascade framework proposed by Haines-Young and Potschin (2010) and further modified by de Groot et al. (2010), La Notte et al. (2017), Matthies et al. (2016), Primmer et al. (2015), and Spangenberg et al. (2014), among others, represents one of the foundations for much ecosystem services research. This framework originally inspired by a production chain metaphor maps the ecosystem service flows between natural systems and human well-being onto a series of consecutive links. These links include ecosystem structures, processes (and/or functions), services, benefits and values. Ecosystem structures, such as forests or wetlands, are sometimes referred to as natural capital, meaning a stock of natural assets from which ecosystem services are derived (Daily et al. 2000, Costanza et al. 2014). The popularity of this

\footnotetext{
${ }^{4}$ Because supporting services do not directly provide benefits to people, they have often been dismissed over concerns about double-counting benefits especially in the context of monetary valuation and ecosystem service accounting (see, for example, Boyd and Banzhaf 2007). Consequently, supporting services have often been recast as intermediate (as opposed to final) services or treated as being synonymous with ecological functions or processes (Potschin-Young et al 2017).
} 
framework is due to the ability to highlight human dependency on natural systems in a straightforward manner. The flexibility of this framework also enables its generalization for a vast array of cases and examples (Potschin-Young et al. 2016).

One of the main concerns regarding the use of the cascade framework regards the inconsistencies identified in the definitions of the links making up the cascade (La Notte et al. 2017, Wallace 2007). For instance, different meanings are associated with the term function, with some authors regarding it as redundant and synonymous with ecological structures and processes (Jax 2005, Wallace 2017, La Notte et al., 2017). Potschin-Young et al. (2017) instead suggest that functional characteristics of a species or ecosystem, e.g. biomechanical properties of trees, are different from ecological structures and processes. Function is used

potential that ecosystems have to deliver a service which in turn depends on ecological structure and

(MEA 2005, Costanza 2017). These inconsistencies complicate attempts to identify, delineate, and quantify links using real-world examples and data in a way that is both objective and unambiguous.

Compared to other elements in the cascade framework, there is less disagreement about the distinction between values and other links in the cascade. According to Wallace and Jago (2017, p. 14), values can be understood as both

existence, including those required for survival and reproductive success, which taken together determine

of human behavior that instrumentally contribute to human wellbei divides values into use and non-use values. The former includes direct and indirect use values. Direct use values include consumptive values (e.g. crops, water, building materials) and non-consumptive values (e.g. recreation). Indirect use values include many supporting and regulating services (MEA 2005), such as pest control, pollination, hydrological regulation, etc. Non-use values include bequest value, altruist value, and existence value. Problematically, th

typologies such as that by Hansjürgens et al. (2017) suggest that values are fixed and universal phenomena. In reality, value is phenomenological determined, meaning that it is assigned subjectively by individuals or groups and it depends on the geographical, historical and socio-economic context (Haines-Young and Potschin 2010, Wallace and Jago 2017).

The cascade framework is a large step forward in clarifying the linkages between ecological structures/processes and human values. Unfortunately, this useful construct is premised on a direct and unilateral relationship between ecosystems and human well-being. In reality, ecosystem services do not flow directly from ecosystems to people. Instead, natural capital contributes to human well-being by producing ecosystem services that interact with other forms of capital, including financial, human, physical and social capital to satisfy basic physiological needs and contribute to education, health, employment, security and the overall health of the social fabric (Costanza et al. 2014, Díaz et al. 2015, 2017). For this reason, Bateman et al. (2011), stress the need to separate the input from natural and human systems when valuing the benefits from ecosystem services. 
In many, if not most cases, tradeoffs exist among individual services as well as groups of services. For example, production of biomass fuels (a provisioning service) can result in short-term tradeoffs with carbon and water regulation services (Caputo et al. 2016). In many other cases, positive synergies can exist between services (i.e. co-benefits); there is a positive link between pollination and crop production, or between air quality regulation and aesthetic landscape values (Smith et al. 2017). Relationships between services are not static; they are complex and vary with context and - particularly - timing. Services that are synergistic over a particular length of time may show tradeoffs over longer or shorter time periods (Renard et al. 2015). Ecosystem services are also positively or negatively influenced by the stock of natural capital and related characteristics, including biotic and abiotic factors, such as habitat, diversity, species/functional groups, and population dynamics (Smith et al. 2017). Because ecosystem services do not occur as isolated phenomena, understanding the relationship between services becomes critical to managing the total impact of ecosystems on human wellbeing (Bennett et al. 2009). Because of tradeoffs in ecosystem services, and due to the phenomenological nature of values assigned to them, it is often recommended that the prioritization of different strategies for their management be decided upon through participatory and deliberative processes among stakeholders. The simultaneous maximization of value from all ecosystem services is, in fact, virtually impossible.

Although many ecosystem services - especially provisioning services - are traded through markets, many other services are not, often because the benefits conferred by these services can be used simultaneously by multiple beneficiaries and/or because it is socially, legally, or physically difficult to constrain benefits to those who have purchased the rights to them. Consequently, markets do not currently capture many ecosystem services, especially regulating and cultural services. This is particularly true for many ecosystem services delivered by family-owned forests, such as carbon storage, water and soil regulation, recreation and other cultural services (Caputo and Butler 2017). The development of artificial markets for ecosystem services has therefore been often proposed as a needed innovation in environmental governance. The idea is to correct traditional market prices to account for real environmental impacts, or to create markets ex novo to include public good-like ecosystem services. The term market-based instruments is loosely used to -and-trade allowances, eco-labels, carbon or biodiversity (Froger et al. 2015, p. 11596). All these instruments are generally expected to follow the principles of additionality, permanence and conditionality, according to which the market transaction should occur only if it guarantees a measurable and long-term additional benefit compared to the status quo. Currently, such artificially created markets focus on biodiversity/habitat conservation and offsetting, carbon sequestration and storage, watershed protection and landscape beauty and recreation (Milder et al. 2010). Sometimes, such markets are also established to address issues of social justice (e.g. REDD+). Historically, most of these new instruments have been publicly-financed (Milder et al. 2010, Hirsch et al., 2011), even though there is increasing interest and engagement by the private sector (TEEB 2012, Waage and Kester 2014). Nonetheless, such new markets often depend on environmental regulations to provide the drive for the private sector demand for ecosystem services.

Several criticisms have been raised towards the ecosystem services concept. The cascade framework is criticized as placing a stronger emphasis on the socio-economic sphere, while the complexity of the ecological sphere is over-simplified (Norgaard 2010, Peterson et al. 2010, La Notte et al. 2017). In addition, it is argued that the utilitarian nature of the ecosystem services concept may undermine the intrinsic value of nature and hamper a holistic vision of ecological resilience and sustainability (Naeem 2013, Díaz et al. 
2015). Similarly, it may place disproportionate emphasis on ecological outputs and under-emphasize underlying biodiversity (Peterson et al. 2010) because it focuses on classifying individual flows of ecosystem services, while underappreciating the role of the stock; and also because much of the influential ecosystem services research has focused on socio-economic benefits rather than the ecological dimensions (Abson et al. 2014). Monetary valuation of ecosystem services is considered not only technically difficult, but also potentially morally hazardous in that it synthesizes value using a single value system. This may lead to impoverishment and denial of other/multiple value systems associated with ecosystem services (Spash 2015). The monetization and exchange of ecosystem services may contribute to nature commodification, according to which environmental quality can be, in principle, bought or sold (GómezBaggethun et al. 2010). A study by Sandbrook et al. (2013) found that even when working on market-based instruments in terms of research or policy guidelines, conservationists are in fact overall critical towards the concept. Furthermore, market instruments often fail to address power asymmetries which lay at the basis of socio-ecological systems (Kosoy and Corbera 2010). While some scholars have suggested that he ecosystem services literature has been predominantly influenced by monetization and commodification perspectives (Gómez-Baggethun et al. 2010, Silvertown 2015, Spash 2015), and needs therefore to be redirected towards more a inclusive sustainability vision, especially in terms of social justice (Schröter et al. 2017), some scholars have found that ecosystem services research has already experienced a reflective and transformative process which has partly internalized and addressed the above-mentioned criticisms and shortcomings (Potschin et al. 2016, van den Belt and Stevens 2016). It is important to reiterate that ecosystem services do not require the existence of a market to qualify as services; services occur wherever ecosystems contribute to the well-being of people.

2. Ecosystem services in the service-dominant logic (SDL) framework

Presenting forest ecosystems as complex systems with productivity potential is not a new idea stemming solely from elements of the ecosystem service framework, but has its roots in traditional forestry sciences (see Caputo 2012, Matthies and Valsta 2016, Matthies et al. 2016 for further discussion) and corresponds well to another branch of service literature: the service-dominant logic (SDL) of marketing sciences (see Vargo and Lusch, 2004, 2006, 2011 and Chapter 2 in this book). The application of a marketing approach to the conceptualization of service has several important uses, particularly in the description and determination of potential value from non-marketed ecosystem service offerings. Over the past decade, there has been a strong push within the ecosystem service literature for a shift towards more integrative ecosystem services valuation (Pascual et al. 2017), including both monetary and non-monetary valuation methods, and more inclusive and equitable governance instruments to administer ecosystem service value

st.

(Vargo et al. 2008). This leads to the conclusion that value is co-created among various societal actors (e.g., forest owners, industrial producers, retailers, end users, and policy makers) through voluntary exchanges

over temporal and spatial scales (Vargo et al. 2008), with a passive yet significant contribution from natural systems (Matthies et al. 2016). Within value networks, firms propose value through market offerings; beneficiaries then continue the value co-creation process by choosing to accept these offerings (Vargo et al. 2008, Matthies et al. 2016). Goods are considered service delivery vehicles and no distinction is made 
between producers and consumers (Vargo et al. 2008). Therefore, only actor-to-actor interactions occur throughout the value network (Storbacka and Lehtinen 2001, Peppard and Rylander 2006, Vargo et al. 2008, Vargo 2009). As a result, there are no final customers per se and value is realized through the

2008, Vargo et al. 20

-in-

not achieved at the exchange. This dual perspective on value (i.e. use and exchange), is not new but rather Wealth of Nations, wher

-in-

-in-

in the SDL, have both direct and indirect market linkages, contributing to both exchange and use value throughout value chains and fit conceptually well within this frame.

The linkages between the ecosystem service and SDL approaches are important, as they relate to ecosystem management impacts throughout the value network. Payne et al. (2008) have noted that it is essential in the marketplace that actors create superior value propositions to maximize the value potential and not destroy value (i.e. destroy attributes of the offering valuable to the beneficiary). Given that the realization of valuein-use is based on undefined experiences, the value to a beneficiary is difficult to determine but vital for continued value co-creation (Zeithaml et al. 2001, Payne et al. 2008, Bocken et al. 2015). Value creation is, therefore, a non-linear interactive and dynamic process that includes determining how environmental impacts and dependencies on ecosystems affect changes in the potential value available to beneficiaries throughout most value networks (Maglio and Spohrer 2008, Bocken et al. 2015, Matthies et al. 2016).

Both value-in-use and exchange also have long been core components in the debate about the societal value of natural ecosystem functions (Gómez-Baggethun et al. 2010). However, the ecosystem services concept, originally framed in a production-oriented approach, has often been seen as lending support to the work of accounting for and valuing non-marketed ecosystem services through monetary valuation methods and the creation of markets for those service offerings (e.g. climate regulation, regulation of genetic and structural

g only on value-in-exchange (Vargo

et al. 2008). Vargo and Lusch (2011) refer directly to this production-oriented perspective as the foundational concept for neoclassical economics views on value and value creation. A firm manufactures value and brings it to market through the exchange of money or other goods, and value-in-exchange is the basis for determining the value of a good or service (Vargo and Morgan 2005, Vargo et al. 2008). Smith and Cannan (2000) also noted that goods with high value-in-use often have low value-in-exchange and vice versa. Therefore, value is created from natural resources to produce market offerings that satisfy the needs or wants of the beneficiary. The focus in the current ecosystem service approach is then placed on supply and demand, where value is ultimately determined via price.

In an article merging the SDL and ecosystem service approaches (Table 1), Matthies et al. (2016) have showed that the SDL can be a useful means for describing the valuation of stocks (i.e. natural capital) and flows (i.e. potential ecosystem services), and impacts on them, that occur as economic and social actors interact with ecological systems through an integrated service value creation (SVC) framework (Fig. 1). The article adopts a concentric circles approach to viewing sustainability dimensions, which postulates mutual inter-relations between three main service systems - economy, environment and society - and in particular the dependence of human well-being and societal development on natural ecosystems (Costanza 
et al. 2014, Folke et al. 2016). In this sens

-reconfiguring system, interacting over various different temporal and spatial scales, loosely arranged using either hard and/or soft contracts, and entailing both value co-creation and -integration by different actors with their

Embedded in this concentric approach, the ecosystem service cascade framework is presented with some modifications, to clearly outline the flow of value potential from ecosystem service offerings through the macro service systems. The authors noted that in reality these flows are not circular, but non-linear interactive exchanges and interactions that are described as value chains and networks. The linkage between the SDL and ecosystem service approach was made following on earlier work regarding the service value potentials related to the ecosystem services cascade (e.g. Gómez-Baggethun et al. 2010, Spangenberg et al. 2014), and the role of ecosystems/environment within the SDL (e.g. Lusch and Vargo 2014, Vargo and Lusch 2017).

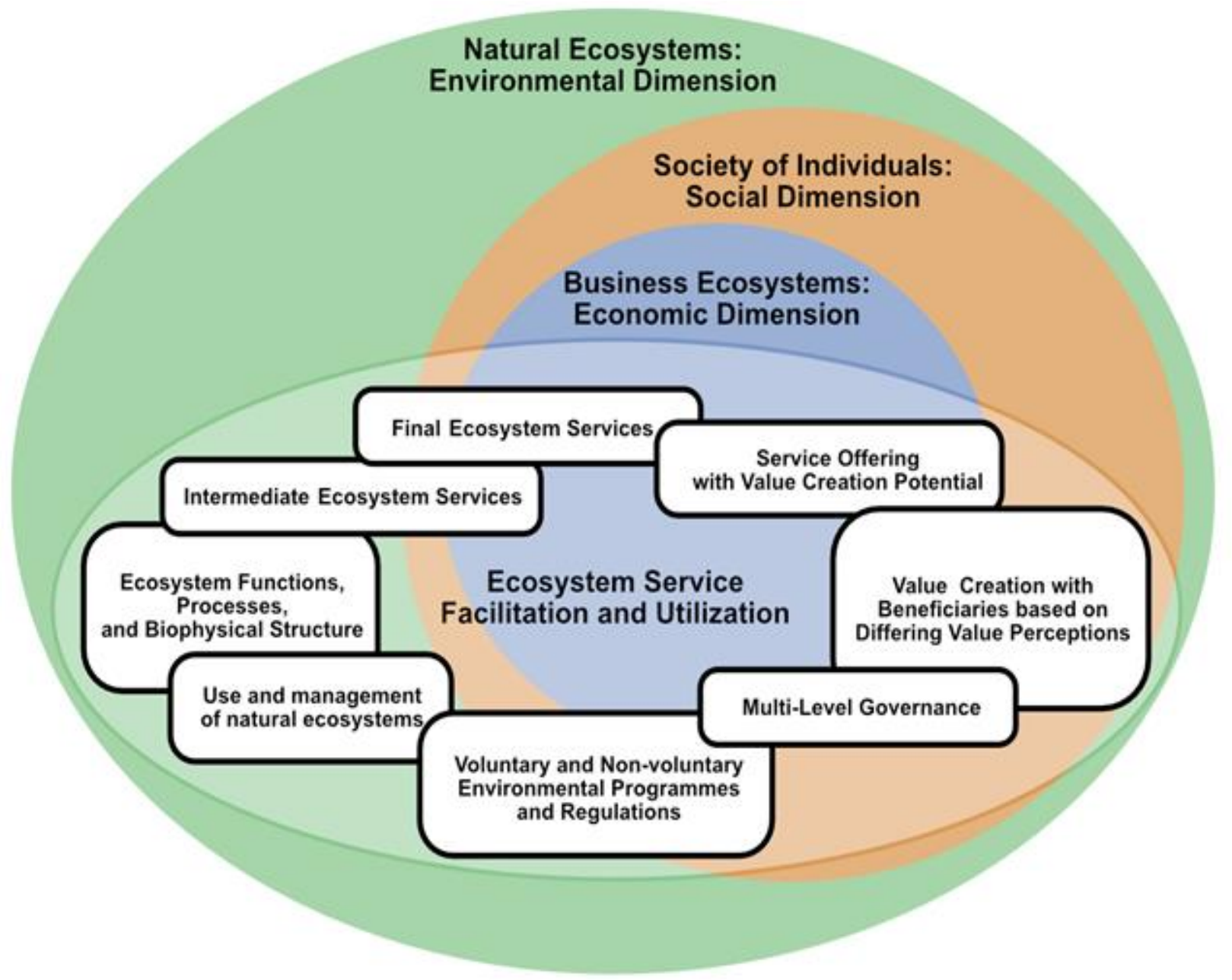

Fig. 1 A service-dominant value creation (SVC) framework for ecosystem service offerings in value cocreation within the socio-ecological system (adopted from Matthies et al., 2016). 
Within the SVC framework, natural ecosystems - such as forests - are recast as service systems and ecosystem services are recast as service offerings (Table 1). These service offerings are the basis of exchange, allowing firms and individuals to co-create value in concert with natural ecosystems. When combined with the definition from Fisher et al. 2009, ecosystem services (now service offerings) become

eople to

create value and improve well-

society and the economy to utilize or facilitate. Therefore, value from ecosystem service offerings is cocreated by utilizing and managing potential value from those offerings, and through further resource integration. Human-based service systems are co-creators and co-destroyers of potential value, through their interaction and management of ecosystems. Management results in impacts to the functions and processes of those ecosystems, and the resulting flow of ecosystem service offerings. Impacts may reduce

-destruction by human-

based service systems may constrain ecosystem service provisioning through management, and create or worsen tradeoffs between offerings (Polasky and Segerson, 2009).

To account for tradeoffs, Matthies et al. (2016) also presented the idea of value-inspatially and temporally dynamic component embedded in value-in-use and exchange, which represents the co-creation and co-destruction of potential value (positive and negative impact) attributed by actors to how ecosystem service offerings are managed, facilitated, and utilized by human-based service systems in

and discussing the portion of value that relates to the co-creation or co-destruction of ecosystem servicerelated value, over varying temporal and spatial scales, for beneficiaries in a value network (Fig. 2). Recent work has noted the importance of how value network stakeholders are integral to value co-creation and the minimization of negative social and ecological impacts over the value chain (Arnold 2017).

The value-in-impact concept provides a basis for understanding how environmental impacts, both positive and negative, can be realized throughout the value creation process. Each actor in the value network will view the value-in-impact component that comprises his or her total value differently. However, the lifetime value of the actor is potentially affected by any actions that destroy value potential; making the recognition of environmental impacts by businesses increasingly important for corporate decision-making. The existence of value-in-impact, and its potential for affecting the lifetime value o

been noted by numerous market organizations through recent engagement in climate change initiatives, research and development, and other strategic actions (Boulter 2011, Waage and Kester 2014). Currently several initiatives, such

among others, aim to for provide guidance on how to assess and value impacts in private business decisions and integrate these challenges to private decision-makers processes (Maxwell 2017, GRI 2011, Hanson et al. 2012). 


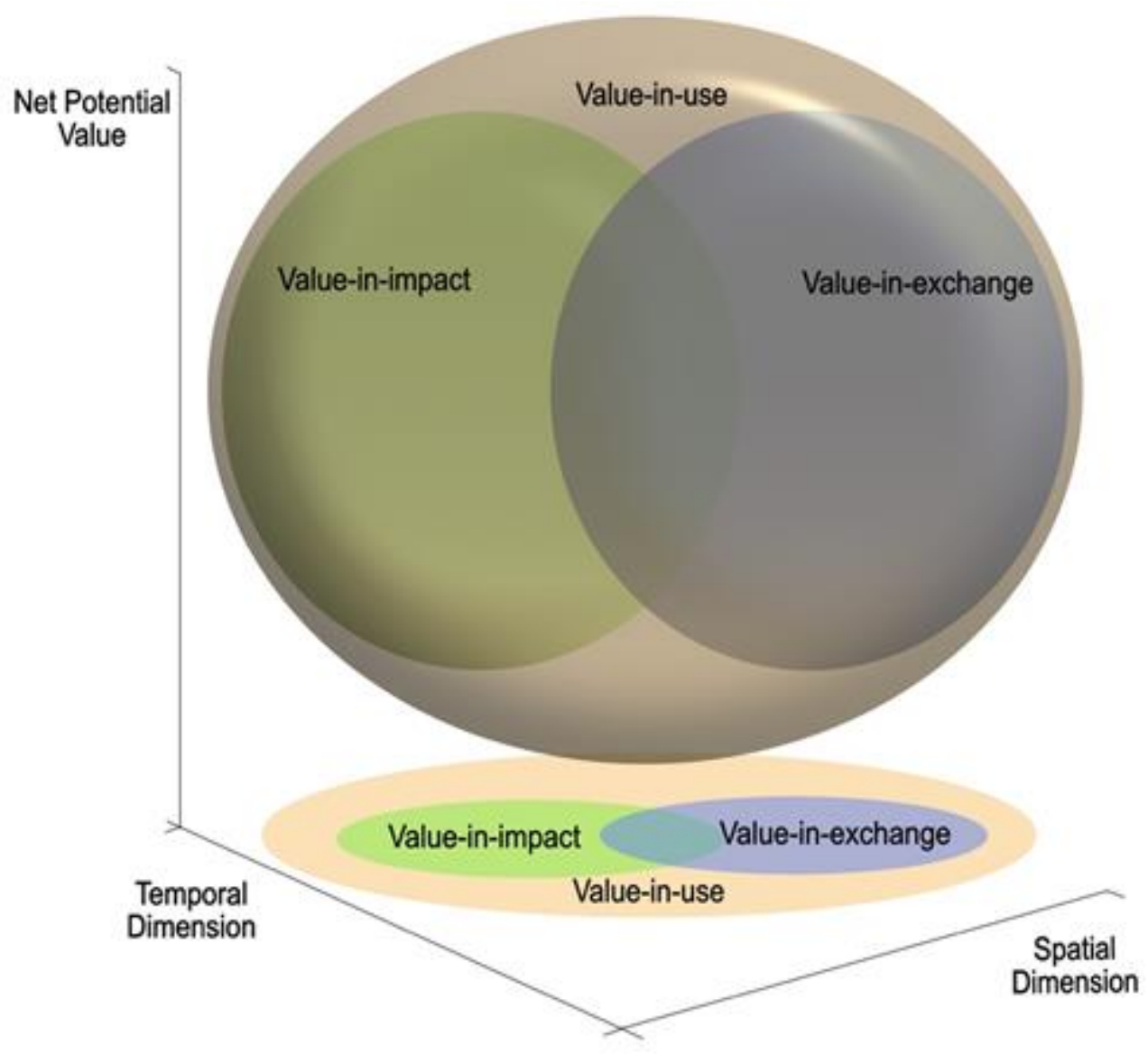

Fig. 2 Role of value-in-impact as a portion of the value-in-exchange and value-in-use of a given service offering. The value-in-impact is both spatially and temporally dynamic. Value-in-use is directionally dependent on value-in-exchange, but value-in-exchange does not need to occur (Adopted from Matthies et al. 2016).

Managing positive and negative impacts from land-use, as is the case in private forestry, is complex with competing spatial and temporal aspects that are increasingly integrated to global decision-making (such as the inclusion of land-use to the Paris Agreement in 2015). The breadth of these challenges demonstrates the importance of a comprehensive view on value creation to allow private forest owners to better manage opportunities in their value networks. A value network is comprised of many different actors interacting to utilize and integrate resources, create or destroy potential value for and with beneficiaries, and provide a business ecosystem to optimize the value potential of service offerings (Maglio and Spohrer 2008, Bocken et al. 2015).

Table 1 Integrating the Ecosystem Service and Service-Dominant Logic Approaches - summary of the proposed improvements to both concepts to improve their underlying definitions.

\section{Concept}




\begin{tabular}{|c|c|c|}
\hline \multirow[t]{2}{*}{ Ecosystem Service } & stem goods and services & $\begin{array}{l}\text { Ecosystem service offerings are the basis of } \\
\text { exchange, where firms/individuals co-create } \\
\text { value with natural ecosystems. }\end{array}$ \\
\hline & $\begin{array}{l}\text { offerings is determined through } \\
\text { value-in- }\end{array}$ & $\begin{array}{l}\text { Value for ecosystem service offerings is the } \\
\text { total potential value, exchange, use, and } \\
\text { impact value, perceived and realized by each } \\
\text { service system through voluntary exchanges. }\end{array}$ \\
\hline Natural Capital & & stock of potential value held by natural \\
\hline \multirow[t]{3}{*}{$\begin{array}{l}\text { Service-Dominant } \\
\text { Logic }\end{array}$} & & $\begin{array}{c}\text { The ecosphere is the largest service system } \\
\text { and an actor in the value creation process that } \\
\text { human service systems interact with and act } \\
\text { upon }\end{array}$ \\
\hline & resources to be integrated by & $\begin{array}{c}\text { Natural ecosystems provide service offerings } \\
\text { with potential value that are utilized or } \\
\text { facilitated by other human-based service } \\
\text { systems. }\end{array}$ \\
\hline & & $\begin{array}{l}\text { Service systems realize and utilize, create } \\
\text { further value from, and/or destroy the } \\
\text { potential value that is created by natural } \\
\text { ecosystems. }\end{array}$ \\
\hline Value Network & $\begin{array}{l}\text { people or organizations creating } \\
\text { social and economic good } \\
\text { through complex dynamic }\end{array}$ & $\begin{array}{l}\text { organizations, or natural ecosystems that } \\
\text { create benefit for human well-being through }\end{array}$ \\
\hline Both approaches & N/A & $\begin{array}{l}\text { Value-in-impact as a conceptual tool for } \\
\text { discussing the positive and negative ES } \\
\text { provisioning impacts throughout the value } \\
\text { creation process }\end{array}$ \\
\hline
\end{tabular}

3. Services from family forest lands

The SVC framework provides a unique perspective on family-owned forests as service systems and as essential actors in value networks, providing multiple service offerings carrying significant potential value. Management and utilization of these forests has important implications for condition of natural capital (stock) and consequently the extent to which potential value is transformed into actual value for human well-

10). In Box 
1, we illustrate a value network map for the forest-based sector adopted from Matthies et al. (2016). As illustrated in this map, actors in a value network interact to utilize and facilitate services in the process of value creation (Peppard and Rylander 2006, Spohrer et al. 2007, 2008, Vargo et al. 2008). Our value network map is used as a lens to explore two examples that we present here. The first example looks at recreational service offerings on family forest lands in the USA, using publically-available data from the U.S. Forest Service National Woodland Owner Survey (NWOS) (Butler et al. 2016). The second example looks at a biodiversity market in Finland, METSO. The METSO Programme has links to the broader European Union goal of enhancing and protecting biodiversity, which has seen a number of Member States of the Union enacting programs to incentivize biodiversity conservation among private landowners. In Finland, the METSO Programme is a public-buyer program where the state aims to voluntarily conserve key habitat types, based on a set of identification criteria graded in a matrix, among private forest owners in areas where conservation potential on public land is limited. Finnish forests, being largely private owned, and especially so in Southern Finland, have demonstrated the potential success of conservation through private incentive mechanisms and value co-creation with a public buyer. Data on the pilot phase of the likainen (2010).

Box 1 A value network map for the forest-based sector (Adopted from Matthies et al. 2016). Value networks are composed of multiple actors, linked by multiple exchanges and interactions (i.e. linkages). Although individual service systems may integrate resources and make service offerings, it is the entire network that collectively co-creates value.

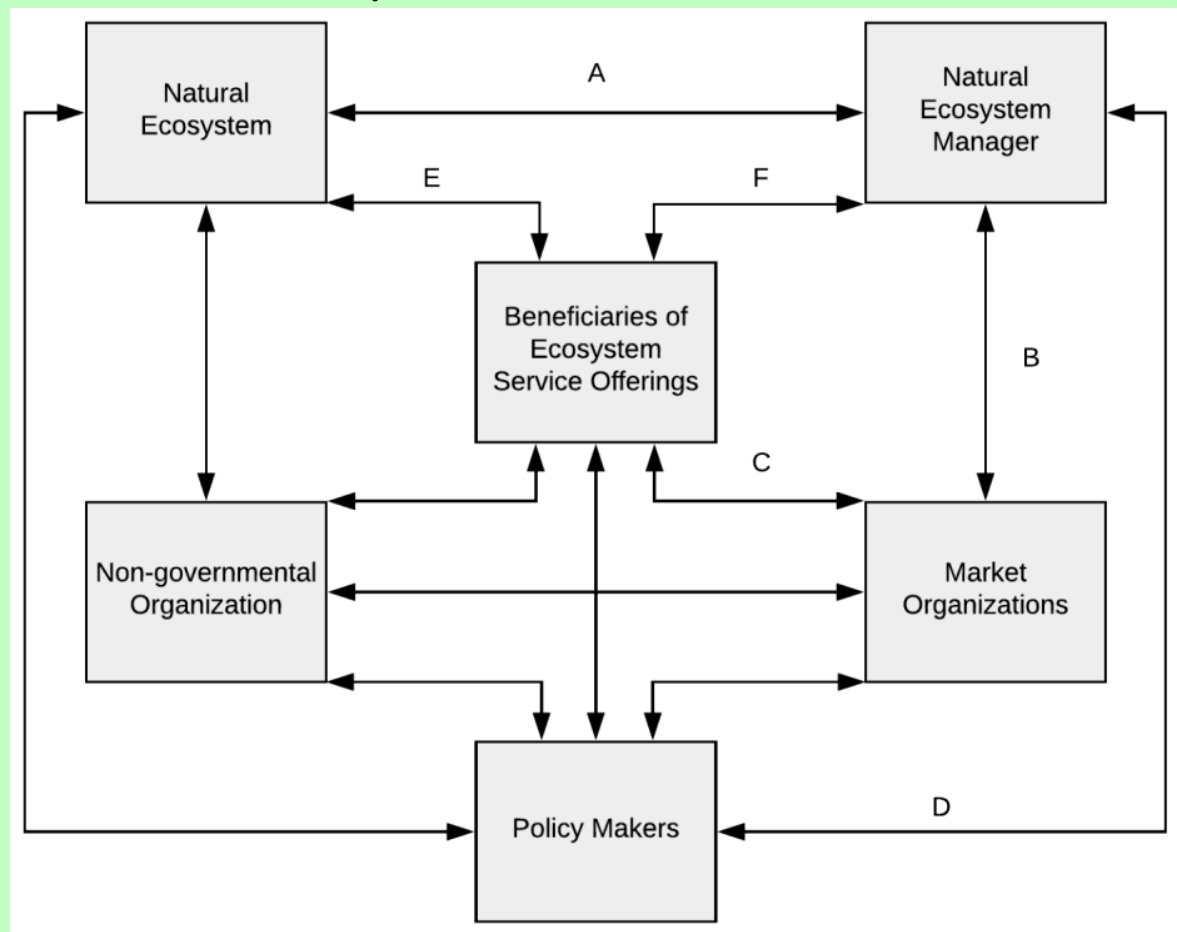

from the natural ecosystem. Managers can both co-create value with the ecosystem directly or utilize the ecosystem service offerings to co-create value with other actors within the value network.

(B) Exchanges between the ecosystem manager and the firm. Value is co-created and potential value of ecosystem service offerings is facilitated to the firm. Firms apply operant resources to the operand 
processes affect the positive and negative impacts on natural ecosystems, and the potential for value destruction results from those actions.

(C) Exchange between the firm and beneficiaries is a value co-creation opportunity. The beneficiary system utilizes the potential value of the service offerings. This includes both the aspects of the potential value associated with ecosystem services offerings and those associated with the application of operant resources by the firm. The aspects associated with the value of service offerings can be viewed as the value-in-impact component. The destruction of potential value by the firm, through their impact on natural ecosystems, is transferred to the beneficiary.

(D) Policy makers are one actor that can determine if governance changes are need to limit value destruction with the larger service system (i.e., economy). Some aims of improved governance are the reduction in tradeoffs from natural ecosystem management decisions and the communication of impacts to beneficiaries.

(E) Interactions between beneficiaries and natural ecosystems can result in direct exchanges of service offerings between them.

(F) The beneficiary and the natural ecosystem manager can be the same actor or multiple actors, which demonstrates the non-linear and dynamic nature of the value network.

Although the value network map illustrated in Box 1 can be applied to almost any value network, not all the actors it depicts are equally important in all networks. The ecological, social, legal, and governmental contexts within which a network is embedded determine which actors dominate and which are less important. This is true of the examples that follow. Because of this, the network map serves as a useful heuristic for comparing and contrasting the key actors in multiple, sometimes quite different, networks.

\section{3a. Recreation Services from U.S. Family Forest Lands}

The United States has over 330 million ha of forestland, of which $35.6 \%$ of which (118 million ha) is owned by family forest ownerships (FFOs). Almost 4 million FFOs own holdings of 4 or more acres of forest woodland, for a total collective ownership of 109 million ha. This 109 million ha of forestland and the biodiversity, and structural and functional diversity it contains constitutes the natural capital at the center of a value network providing multiple service offerings (Caputo and Butler 2017). In addition to natural capital, private forestlands include significant stocks of physical capital such as roads, trails, docks, and buildings. Within the SVC framework, the forest (including its physical capital) can be seen as a significant source of potential service offerings. That is to say, the forest does not in and of itself provide service offerings, but contributes to value co-creation with landowners, beneficiaries, and other actors.

Recreation is one of the most common benefits provided by U.S. family forestlands. Of the estimated 4 million FFOs, over 3.5 million or $87.2 \%$ own land on which people recreate. Overwhelmingly, the beneficiaries of these service offerings are landowners and their close associates, family, friends, and neighbors (Fig. 3). Only 5.1\% of FFOs own land on which the general public recreates for free; even fewer FFOs have collected fees for this opportunity. Very little of the value in recreation, then, comes from valuein-exchange. Instead, the largest proportion of value constitutes value-in-use, particularly because the value one derives from recreation is inseparable from the actions one takes in recreating. On the diagram in Box 1 , the most important linkages in the value network are between the natural ecosystem (the forest), the 
managers/owners, and the beneficiaries of recreational service offerings (linkages A, E, and F in Box 1). Markets, NGOs, and policies are relatively unimportant actors in this case.

By making choices about when and where to recreate and what activities to undertake recreationalists (the beneficiaries) themselves are essential actors in the co-creation of the value that they derive from their recreation. Hunting, hiking and off-road driving are some of the most popular recreational activities in U.S. family forests (Fig. 4) hunting alone takes places on lands owned by almost $66 \%$ of FFOs. The distribution of these services reflects the values and interests of beneficiaries, as well as their skills and resources. For example, hunters require habitat and game animals to be able to hunt but they also need to contribute their own abilities in the form of marksmanship, tracking, and other skills. This linkage between the forest ecosystem and the beneficiaries (linkage E in Box 1) is a critical one in this particular value network.

Family forest owners in the USA generally serve as the primary managers of their forest lands; only a small percentage use the services of professional foresters (i.e. over $80 \%$ of FFOs have received no professional advice regarding the management of their lands). These owners/managers participate in the co-creation of value by managing their forests to increase the potential for service offerings (linkage A in Box 1). In doing so, they affect value-in-impact by making decisions about the management of tradeoffs. In the case of recreational services, 2.0-23.6\% of FFOs engage in activities expected to increase recreational values (Fig. 5); these include managing fire, invasive species, insect and diseases, and wildlife habitat. In addition to these activities, which affect natural capital, landowners maintain and create trails and roads key aspects of physical capital in the forest ecosystem. Along with management, landowners participate in the cocreation of value by allowing potential beneficiaries to recreate on their lands (linkage F in Box 1). This is possible because U.S. laws grant landowners the right to exclude individuals from their land. In fact, more than $52.2 \%$ of landowners post their land against hunting, trespassing, off-road driving, or other activities (Fig. 6). When landowners choose to exclude recreationalists from their land, their decision results in the destruction (rather than co-creation) of value in that they ensure that these potential service offerings are not realized. 


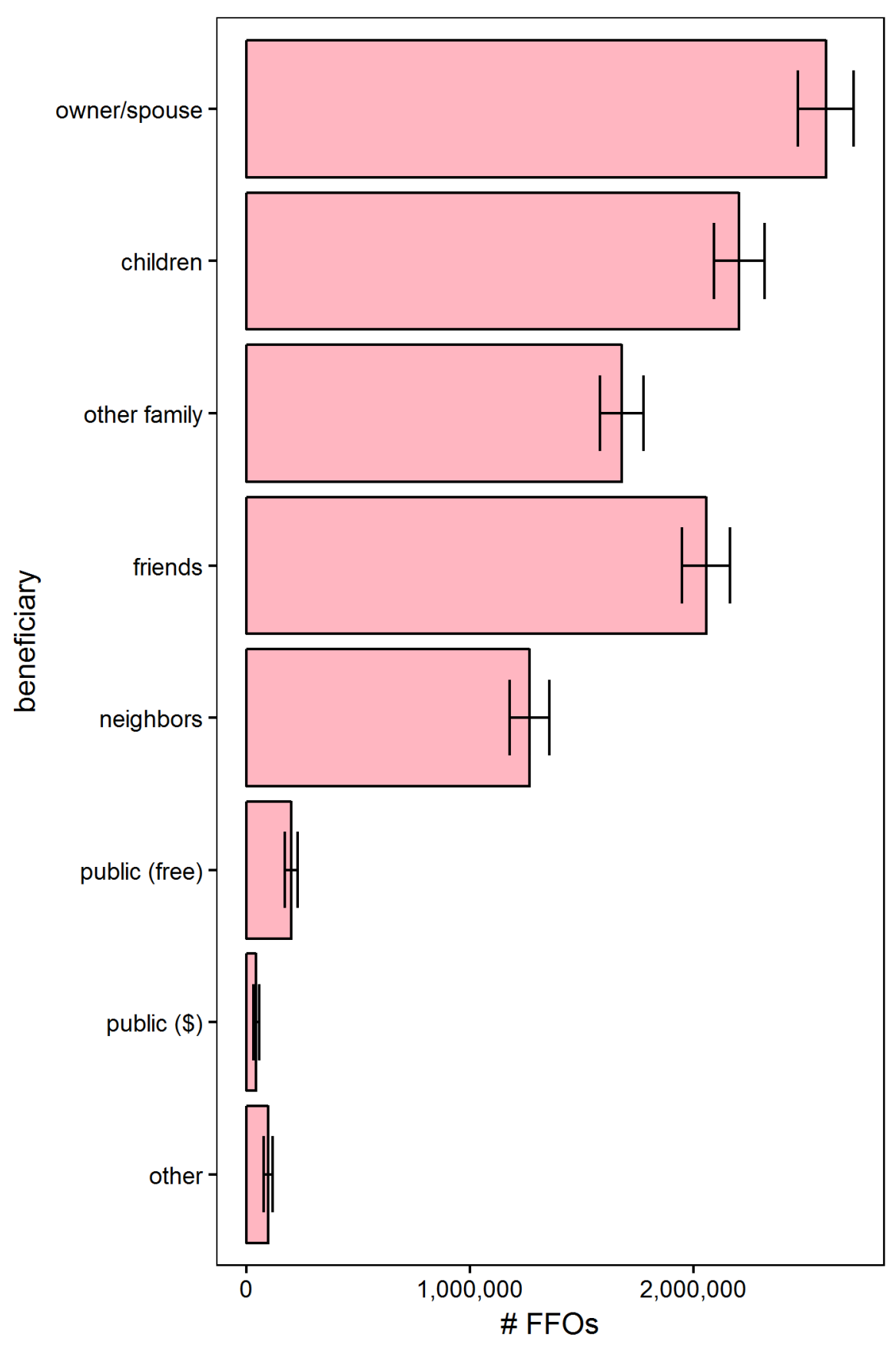

Fig. 3 Beneficiaries of recreational service offerings on family forest lands, USA. Numbers of family forest ownerships by beneficiary. Error bars are equal to two standard errors. 


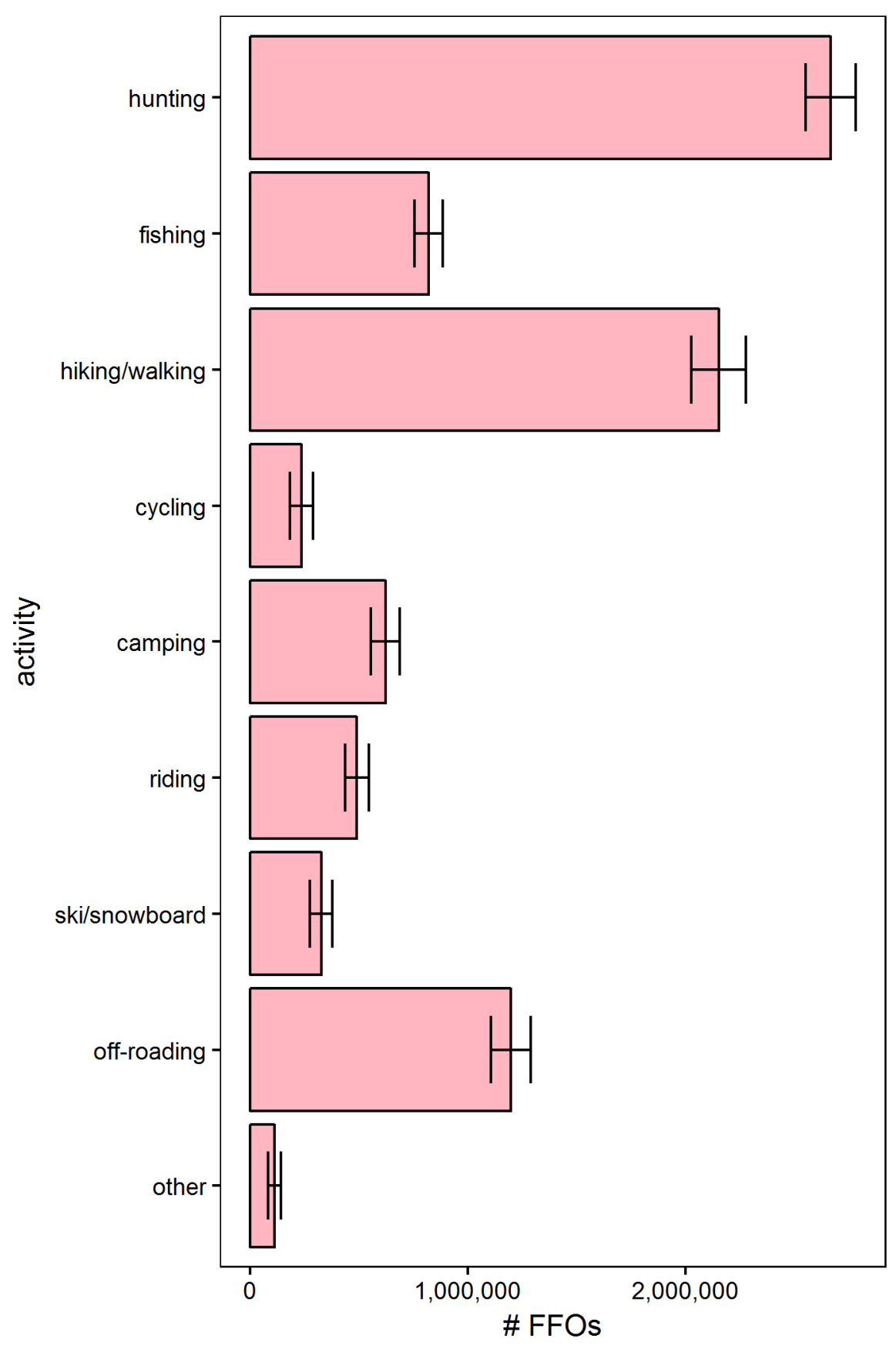

Fig 4 Recreational activities on family forests, USA. Number of family forest ownerships by recreational activity. Error bars are equal to two standard errors. 


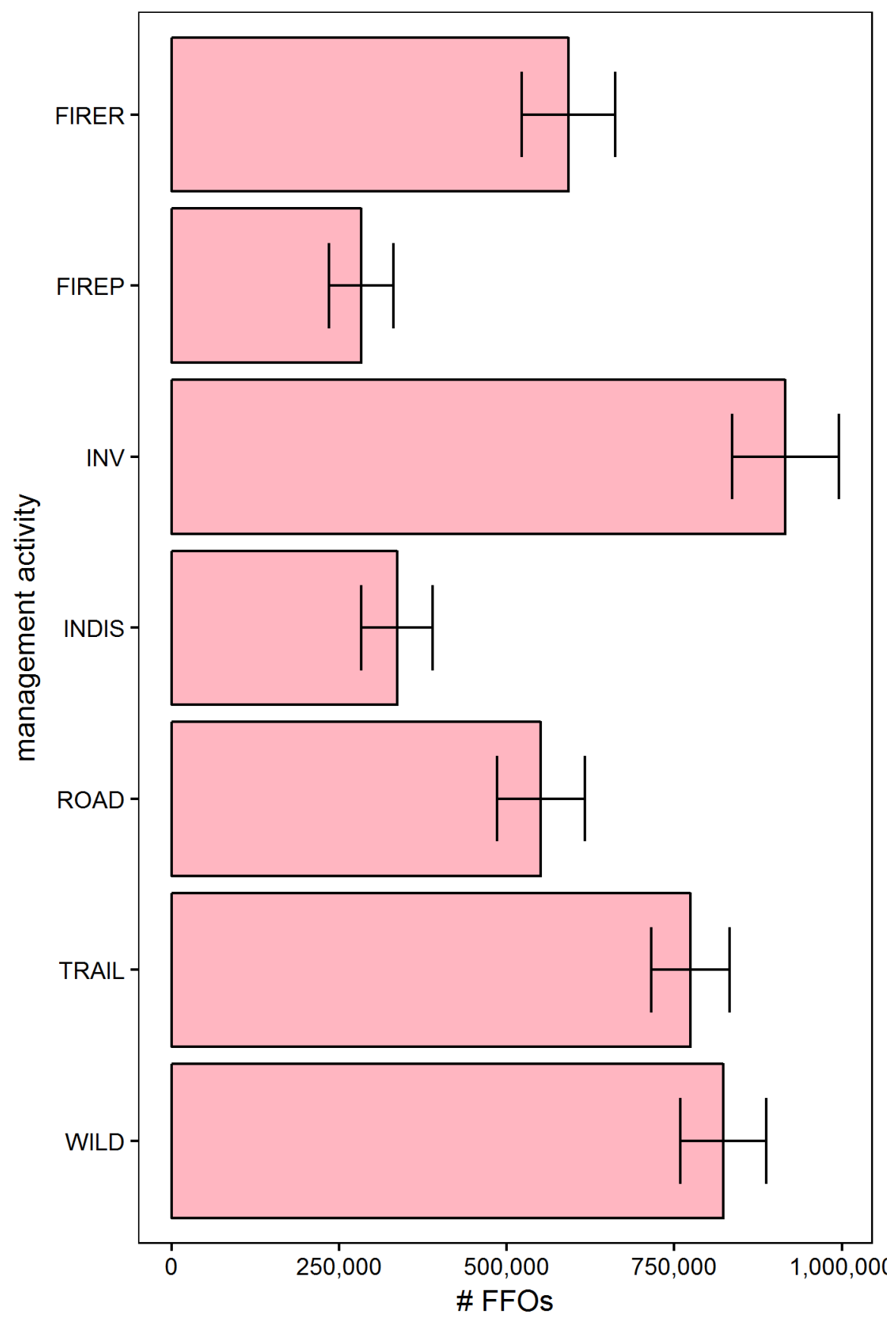

Fig. 5 Management activities on family forest lands, USA. Number of family forest ownerships by management activity. Error bars equal two standard errors. 


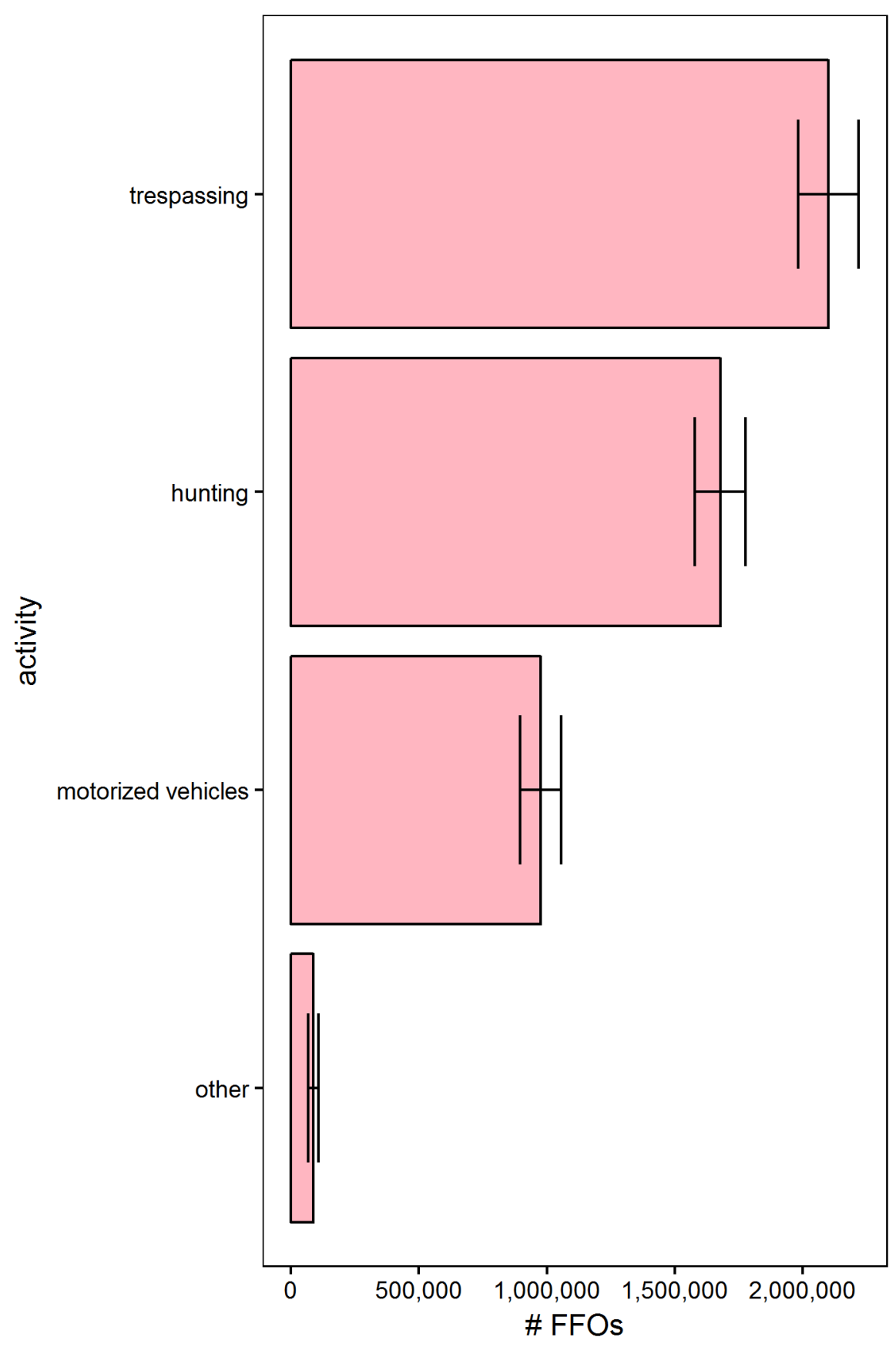

Fig. 6 Excluded activities in family forest lands, USA. Number of family forest owners by activity posted. Error bars equal two standard errors.

3b. Biodiversity markets in Finland and their relationship to the relevance and accessibility of ecosystem service offerings in Finnish forests

Forests represent $75 \%$ of the land cover in Finland. The yearly export value of forest products in Finland is over 10 billion euros representing about $20 \%$ of the total exports (Jäppinen and Heliölä 2015, p. 30). In 
addition to forest products having historically been an important component of the Finnish economy, other important benefits related to ecosystem services include bioenergy, non-wood forest products (e.g. berries, mushroom, birch sap, lichens), hunting and reindeer herding, water regulation and purification, and outdoor recreation, such as collection of non-wood forest products, cross-country skiing, hiking, and birdwatching (Kettunen et al. 2012, Jäppinen and Heliölä 2015).

In Finland, family forests constitute 53\% of the overall forestry land and $61 \%$ of the productive forest land; other owners include the state (35\% and 25\% respectively); industrial private companies (7\% and $8 \%$ ) and others (5\% and 5\%) (Finnish Forest Association 2017).

The beneficiaries of Finnish forest services extend far beyond landowners and associates (e.g. friends, Jokamiehenoikeus) allow free access for all citizens to public and private land and waterways, including the collection of natural products for recreational and even commercial use. Restrictions are enforced for boating, fishing, hunting and timber collection, for access to protected species and areas, and for activities which damage the environment or disturb others. This legislative arrangement, derived from medieval land ownership traditions shared by the Nordic Countries, contrasts with the private property rights regimes found for instance in most southern

Nordic culture and national identity (Kettunen et al. 2012, p. 82). As a result, all Finnish and many nonFinnish people benefit from many forest ecosystem service offerings. For instance, $96 \%$ of the national population engage in outdoor recreation annually (Jäppinen and Heliölä, 2015, p. 34), including extractive (e.g. berry or mushroom picking) and non-extractive (e.g. boating, hiking) activities. An important infrastructural component to the co-creation of cultural services are cottages (in Finnish, mökki), to which over $60 \%$ of Finns have access (Kettunen et al. 2012, p. 177), and which represent an indissoluble component of the Finnish nature experience.

In this context of fragmented forest ownership and multiple service beneficiaries, Finland has hosted an example of a market-like scheme for nature conservation, namely the METSO Forest Biodiversity Programme (or METSO), which began in 2008 and is ongoing. The aim of the programme has been to protect forest habitats and species, based on voluntary and custom-fit agreements with forest owners. By valuing and protecting the biodiversity (i.e. the natural capital) upon which they depend, this program seeks to place value on and preserve the many potential ecosystem service offerings provided by Finnish family forests (Haines-Young and Potschin 2010; MEA 2005). METSO payments, however, are not conditional on any particular ecosystem or service outcomes, but to a change towards a desired land management status (i.e. passive conservation in place of active management). Forest owners have been able to either set-aside the designated area from harvesting for 20-year contracts, sell the forest area to the state for permanent protection or retain ownership of the site with a payment to create a private protected area. Prices for METSO contracted forests reflected conservation costs, opportunity costs (i.e. timber harvesting), and the biodiversity value of the forest (measured using a matrix of key indicators) (Juutinen and Ollikainen 2010, Metsonpolku 2016). The current budget for METSO outlines a continuation of the Programme up to, at least, 2025 with an objective of 82,000 hectares secured through contracts in commercial forests.

METSO has been an important first step in the development of a private market for biodiversity and ecosystem service provisioning in Finland, and one of the first of such initiatives in Europe. On the basis of METSO, habitat banking and voluntary conservation contracting have been postulated as ways to move 
nature conservation in private forests forward from a public compensation scheme towards market-based methods (Jäppinen and Heliölä 2015, Laininen and Matthies 2017). Recent developments indicate that there is strong interest in continuing to build

Helsinki University and the Finnish Environment Institute that has reviewed the scope of biodiversity offsetting through a habitat banking concept) and private (e.g. the development of conservation impact investments by the company Dasos Capital, which is a European timberland fund manager) market actors in Finland and across Europe.

Optimizing management for biodiversity objectives, something that METSO promotes through financial incentives, can have important implications for achieving other ecosystem service objectives through active or passive forest management. Research has demonstrated that, for example, climate regulating service objectives cannot always be fully met without resulting in tradeoffs with biodiversity objectives (e.g. see Matthies et al. 2016). Understanding tradeoffs from forest management is critical, as they often lead to lost benefits (i.e. negative value-in-impact). Private forest managers often differ in their preferences and values regarding these types of tradeoffs, making the achievement of increased ecosystem service provisioning a challenge across the landscape (Matthies et al. 2018).

In terms of the value network in Box 1, the biodiversity represented by Finnish forests - and valued through METSO - serves as the underpinning for multiple final service offerings enjoyed by beneficiaries (linkage $E$ in Box 1). Stands enrolled in the pilot phase of the program (2003-2004) differed in terms of the extent and quality of the biodiversity they contained (Fig. 7) and were presumed, therefore, to differ in terms of their inherent potential to provide different types of service offerings ${ }^{5}$. As we highlighted in the previous section, beneficiaries are not passive recipients of these services; they act as active co-creators of value in the choices they make regarding ecosystem management as well as the skills and resources they bring to the enjoyment of Nature.

As mentioned, national laws in Finland allow anyone to perform various recreational activities also on

recreation activities, as seen in the USA. Rather, forest owners participation in value co-creation regards their management decisions (linkage A in Box 1). Those owners engaged in METSO, for instance, contribute to nature conservation and therefore to the co-creation and maintenance of various ecosystem service offerings, including, among others, habitat maintenance, aesthetic beauty, cultural identity and recreation opportunities. In some few cases, these landowners engaged in conservation management activities specifically as a result of the conservation contracts; in all cases, they withheld from timber management activities that could have interfered with conservation objectives.

In the U.S. example, recreational services were distributed through informal channels and policies (linkage F in Box 1) and markets (linkage B in Box 1) were relatively unimportant. The same is true in Finland for

benefit from private lands for free and, thus, serve as a major obstacle to the formation of market-based exchanges. Government policies (linkage D. in Box 1) - in this case METSO - serve instead to provide price mechanisms to reward landowners for providing public services. For example, contracts awarded in 2003

\footnotetext{
${ }^{5}$ Although this presumption is likely to be broadly true for many different types of services (e.g. bird watching), the relationship between biodiversity and human welfare is complex and context-dependent. See, for example, Harrison et al. 2014.
} 
and 2004 for the pilot phase of METSO Programme paid between 200 -

${ }^{-1}$ to participating landowners (Figure 8). By contrast, this linkage is relatively unimportant in the U.S. example.

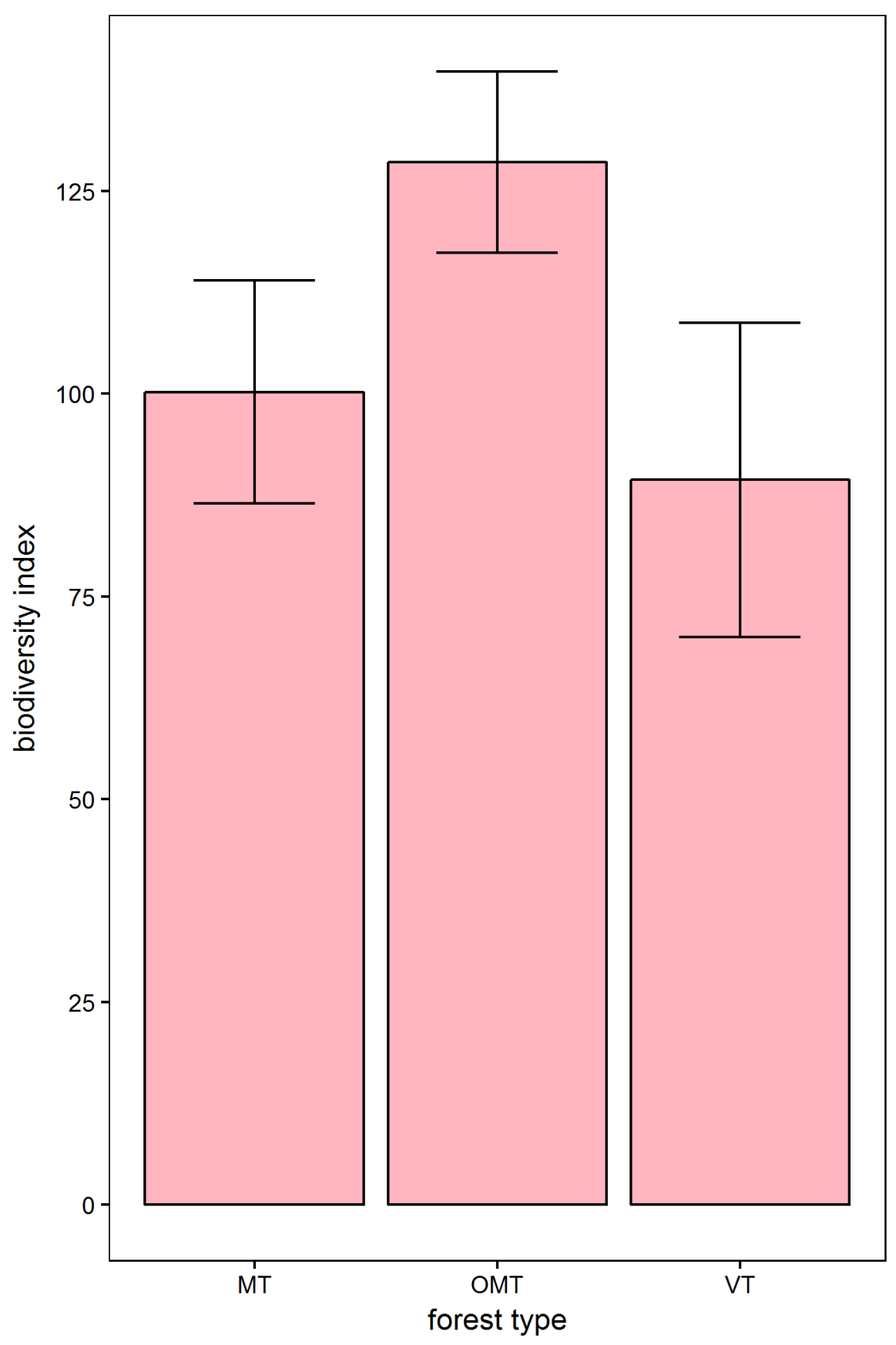

Fig. 7 Biodiversity index value of forest stands enrolled in the Finnish METSO program (pilot phase) by Forest Type, 2003-2004 ( $\mathrm{n}=72$ stands). Forest Type: $\mathrm{MT}=$ mesic forest, OMT = herb-rich forest, VT = xeric forest. Biodiversity index based on stand size, structural complexity, species mix, dead wood, water, 
and proximity to conservation areas (Juutinnen and Ollikainen 2010). Error bars equal two standard errors.

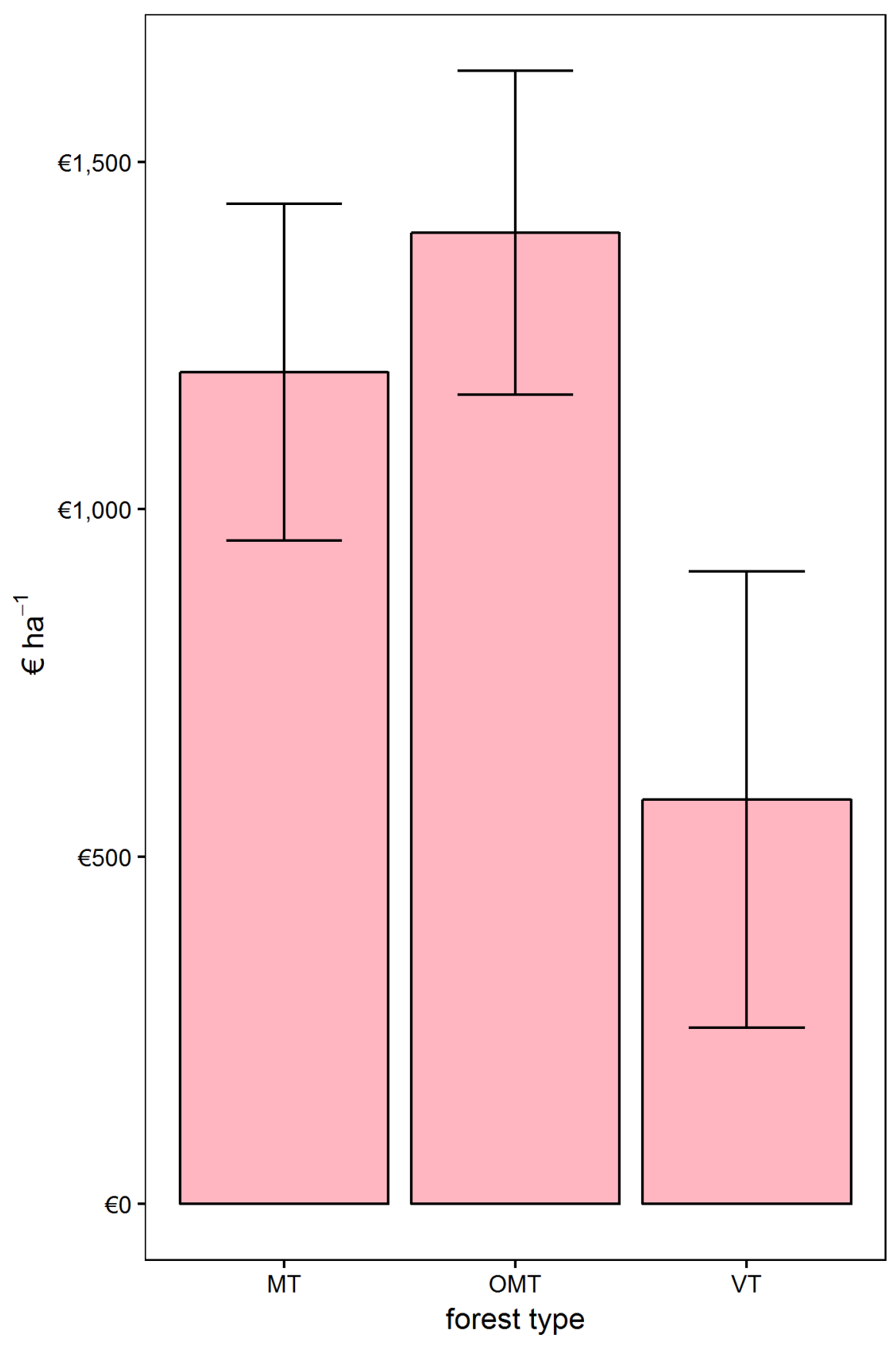

Fig. 8 Payments made for biodiversity conservation in forest stands enrolled in the Finnish METSO program (pilot phase) by forest type, 2003-2004 ( $\mathrm{n}=72$ stands). Forest Type: $\mathrm{MT}=$ mesic forest, OMT $=$ herb-rich forest, VT = xeric forest. Error bars equal two standard errors.

4. Conclusions 
The marriage of ecosystem services theory and SDL as in the integrated service value creation (SVC) framework described in this chapter promises an informative perspective through which to view the role of forests and woodlands in promoting human welfare. Ecosystem services theory and thinking can offer a deeper conceptualization of the role of natural systems in SDL theory by revealing and characterizing the dependent relationship between social-economic systems and the environment (Folke et al. 2016). Scholars have noted, however, that the current service science literature has yet to fully integrate the ecosystem services approach within the value creation literature (Matthies et al. 2016, Lusch and Vargo 2014, Vargo and Lusch 2017). On the other hand, SDL can contribute to shifting the conceptualization of ecosystem services away from a GDL, by which it has traditionally been inspired. This would respond to the current calls in the research community for a more integrated approach to ecosystem services conceptualization and valuation (e.g. Schröter et al. 2017, van den Belt and Stevens 2016), with an emphasis on the role of non-marketed services, the role of policies in driving service provision, and the management of tradeoffs throughout the entire value network.

Using the SVC as a framing device, we compared and contrasted two different examples of forest value networks biodiversity markets in Finland and recreational services in U.S. family forests. In both cases, forests comprise significant stocks of natural and physical capital with significant value potential for beneficiaries. In both cases, value is co-created from the combined efforts of landowners, land managers, and beneficiaries. In the U.S. example, landowners frequently exercise their legal right to exclude potential recreationalists from their land and value (in the form of recreational opportunities) is realized primarily by the landowners themselves, along with family and friends. Markets and policies are relatively unimportant. In the Finnish example, on the other hand, biodiversity markets served a key role in safeguarding the natural capital necessary for the creation of value in the form of recreation and non-timber forest products. Because xclude people from engaging in these activities on their land, and, consequently, the sphere of potential beneficiaries served by biodiversity markets was large. The SVC provides a means for describing the difference in importance among different actors and forms of capital across multiple value networks, and consequently, to draw conclusions regarding the potential for value production in those networks. This is key to a better understanding of the complex relationship between forests and human welfare, as well as the potential role of new policies, markets, and social institutions in promoting and maintaining the creation of value. 


\section{References}

Abson, D.J., von Wehrden, H., Baumgärtner, S., Fischer, J., Hanspach, J., et al. (2014). Ecosystem services as a boundary object for sustainability. Ecological Economics, 103, 29-37.

Arnold, M. 2017. Fostering sustainability by linking co-creation and relationship management concepts. Journal of Cleaner Production, 140,179-188.

Bateman, I.J., Mace, G.M., Fezzi, C., Atkinson, G., Turner, K. (2011). Economic analysis for ecosystem service assessments. Environmental and Resource Economics, 48, 177218 (2011). doi:10.1007/s10640-010-9418-x

Bennett, E. M., Peterson, G. D. \& Gordon, L. J. (2009). Understanding relationships among multiple ecosystem services. Ecology Letters, 12, 13941404.

Bocken, N.M.P., Rana, P., Short, S.W. (2015). Value mapping for sustainable business thinking. Journal of Industrial and Production Engineering, 32(1), 67-81.

Boulter, J. (Ed). (2011). Approach for Reporting on Ecosystem Services: Incorporating Ecosystem Services 8866-0528.

Global Reporting Initiative. ISBN: 978-90-

Boyd, J., Banzhaf, S. (2007). What are ecosystem services? The need for standardized environmental accounting units. Ecological Economics, 63, 616626.

Butler, B.J., Hewes, J.H., Dickinson, B., Andrejczyk, K., Butler, S.M., Markowski-Lindsay, M. (2016). USDA Forest Service National Woodland Owner Survey: National, regional, and state statistics for family forest and woodland ownerships with 10+ acres, 2011-2013, Res. Bull. NRS-99 (Newtown Square, PA: U.S. Department of Agriculture, Forest Service, Northern Research Station).

Caputo, J. (2012). Commoditization and the Origins of American Silviculture. Bulletin of Science, Technology \& Society, 32, 8695.

Caputo, J., Beier, C.M., Groffman, P.M., Burns, D.A., Beall, F.D., et al. (2016). Effects of Harvesting Forest Biomass on Water and Climate Regulation Services: A Synthesis of Long-Term Ecosystem Experiments in Eastern North America. Ecosystems, 19, 271283.

Caputo, J., Butler, B. (2017). Ecosystem Service Supply and Capacity on U.S. Family Forestlands. Forests, 8(10), 395, doi:10.3390/f8100395.

Chen, W., Chen, J. M., Price, D. T., Cihlar, J., and Liu, J. (2000) Carbon Offset Potentials of Four Alternative Forest Management Strategies in Canada: A Simulation Study. Mitigation and Adaptation Strategies for Global Change, 5(2), 143-169.

Costanza, R., de Groot, R., Braat, L., Kubiszewski, I., Fioramonti, L., et al. (2017). Twenty years of ecosystem services: How far have we come and how far do we still need to go? Ecosystem Services, 28, 116.

Costanza, R., de Groot, R., Sutton, P., van der Ploeg, S., Anderson, S.J., et al. (2014). Changes in the global value of ecosystem services. Global Environmental Change, 26, 152158. 
Costanza, R. (2008) Ecosystem services: Multiple classification systems are needed. Biological Conservation, 141, 350352.

D'Amato, D., Rekola, M., Wan, M., Cai, D., Toppinen, A. (2017). Effects of industrial plantations on ecosystem services and livelihoods: Perspectives of rural communities in China. Land Use Policy, 63, 266-278.

Daily, G.C., Soderqvist, T., Aniyar, S., Arrow, K., Dasgupta, P., et al. (2000). The Value of Nature and the Nature of Value. Science, 289, 395396.

Davies, L., Kwiatkowski, L., Gaston, K.J., Beck, H., Brett, H., et al. (2011). Urban, Chapter 10. In UK National Ecosystem Assessment, The UK National Ecosystem Assessment Technical Report. (pp 361 410). UNEP-WCMC, Cambridge.

de Groot, R.S., Alkemade, R., Braat, L., Hein, L., Willemen, L, (2010). Challenges in integrating the concept of ecosystem services and values in landscape planning, management and decision making. Ecological Complexity, 7, 260272.

Díaz, S., Demissew, S., Carabias, J., Joly, C., Lonsdale, M., et al. (2015). The IPBES Conceptual Framework - connecting nature and people. Current Opinion in Environmental Sustainability, 14, 1-16.

Eriksson, E., Gillespie, A. R., Gustavsson, L., Langvall, O., Olsson, et al. (2007) Integrated carbon analysis of forest management practices and wood substitution. Canadian Journal of Forest Research, 37(3), 671-681.

Fisher, B., Turner, R.K., Morling, P. (2009). Defining and classifying ecosystem services for decision making. Ecological Economics, 68, 643653.

Finnish forest association. (2017). Forest ownership. https://www.smy.fi/en/forest-fi/graphs/forestowners/. Accessed 19 January 2018.

Folke, C., Biggs, R., Norström, A. V., Reyers, B., Rockström, J., (2016). Social-ecological resilience and biosphere-based sustainability science. Ecology and Society, 21(3), 41, doi:10.5751/ES08748-210341.

Froger, G., Boisvert, V., Méral, P., Le Coq, J.F., Caron, A., et al. (2015). Market-based instruments for ecosystem services between discourse and reality: An economic and narrative analysis. Sustainability, 7(9), 1159511611.

Gómez-Baggethun, E., de Groot, R., Lomas, P.L., Montes, C. (2010). The history of ecosystem services in economic theory and practice: From early notions to markets and payment schemes. Ecological Economics, 69, 12091218.

GRI. (2011). Approach for reporting on ecosystem services: Incorporating ecosystem services into an organizational performance disclosure. The Global Reporting Initiative.

Grönroos, C. (2008). Service logic revisited: who creates value? And who co-creates?. European Business Review, 20(4), pp.298-314.

Haines-Young, R., Potschin, M., (2013). CICES V4.3 - Report prepared following consultation on CICES Version 4. EEA Framework Contract No EEA/IEA/09/003. 
Haines-Young, R., Potschin, M., (2010). The links between biodiversity, ecosystem services and human well-being. In Raffaelli, D., Frid, C. (eds.), Ecosystem Ecology: a New Synthesis, (pp. 110 139). BES Ecological Reviews Series, CUP, Cambridge.

Hansjürgens, B., Schröter-Schlaack, C., Berghöfer, A., Lienhoop, N. (2017). Justifying social values of nature: Economic reasoning beyond self-interested preferences. Ecosystem Services, 23, 9 17.

Hanson, C., Ranganathan, J., Iceland, C., Finisdore, J. (2012). The Corporate Ecosystem Services Review: Guidelines for identifying business risks and opportunities arising from ecosystem change. Version 2.0. World Business Council for Sustainable Development.

Harrison, P.A., Berry, P.M., Simpson, G., Haslett, J.R., Blicharska, M., Bucur, M., Dunford, R., Egoh, B., Garcia-Llorente, M., Geamana, N., et al. (2014). Linkages between biodiversity attributes and ecosystem services: A systematic review. Ecosystem Services, 9, 191203.

Hirsch, F., Clark, D. Vihervaara, P., Primmer, E., (2011). Payments for Forest related Ecosystem Services: What role for a Green Economy? (Workshop Paper).

Jäppinen, J.P., Heliölä, J.P. (2015). Towards a sustainable and genuinely green economy: the value and social significance of ecosystem services in Finland. The Finnish Ministry of Environment, Helsinki.

$\operatorname{Jax}$

Oikos, 111(3), 641-648.

Juutinen, A., Ollikainen, M. (2010). Conservation contracts for forest biodiversity: theory and experience from Finland. Forest Science, 56, 201211.

(2012). Socio-economic importance of ecosystem services in the Nordic Countries: Synthesis in the context of The Economics of Ecosystems and Biodiversity (TEEB). Nordic Council of Ministers.

Kosoy, N., Corbera, E. (2010). Payments for ecosystem services as commodity fetishism. Ecological Economics, 69, 12281236.

Laininen, J., Matthies, B.D. (2017). How private finance can raise efficiency in conservation markets. Environmental Finance. https://www.environmental-finance.com/content/analysis/howprivate-finance-can-raise-efficiency-in-conservation-markets.htm. Accessed 28 September 2017.

(2017). Ecosystem services

classification: A systems ecology perspective of the cascade framework. Ecological Indicators, 74, 111.

Landers, D.H., Nahlik, A.M. (2013). Final ecosystem goods and services classification system (FEGS-CS). Report number EPA/600/R-13/ORD-004914. United States Environmental Protection Agency (EPA).

Lusch, R. F., Vargo, S. L. (2014). Service-dominant logic: Premises, Perspectives, Possibilities. Cambridge University Press, Cambridge, U.K.

Maglio, P.P. and Spohrer, J., 2008. Fundamentals of service science. Journal of the Academy of Marketing Science, 36(1), 18-20. 
Dominant Logic? Integrating the ecosystem service approach and the service-dominant logic. Journal of Cleaner Production, 124, 5164.

Matthies, B.D., Kalliokoski, T., Eyvindson, K., Honkela, N., Hukkinen, J.I., et al. (2016). Nudging service providers and assessing service trade-offs to reduce the social inefficiencies of payments for ecosystem services schemes. Environmental Science and Policy, 55, pp.228-237.

Matthies, B.D., Vainio, A., D'Amato, D. (2018). Not so biocentric environmental benefits and harm associated with the acceptance of forest management objectives by future environmental professionals. Ecosystem Services, 29, 128-136.

Matthies, B.D., Valsta, L.T. (2016). Optimal forest species mixture with carbon storage and albedo effect for climate change mitigation. Ecological Economics, 123, 95-105.

Maxwell, D. (2017). Valuing Natural Capital: Future Proofing Business and Finance. Routledge.

Metsonpolku. (2016). METSO Forest Biodiversity. http://www.metsonpolku.fi/en-US. Accessed 19 January 2018.

Milder, J.C., Scherr, S.J., Bracer, C., (2010). Trends and future potential of payment for ecosystem services to alleviate rural poverty in developing countries. Ecology and Society, 15(2), 4.

Millenium Ecosystem Assessment. (2005). Ecosystems and human well-being: synthesis. Island Press, Washington, D.C.

Müller, F., Burkhard, B. (2012). The indicator side of ecosystem services. Ecosystem Services, 1, 2630.

Naeem, S. (2013). Ecosystem Services: Is a Planet Servicing One Species Likely to Function? In Rozzi, R. (Ed.), Linking Ecology and Ethics for a Changing World: Values, Philosophy, and Action, (pp. 303 321). Springer, New York.

Norgaard, R. B. (2010). Ecosystem services: From eye-opening metaphor to complexity blinder. Ecological Economics, 69, 12191227.

Pascual, U., P. Balvanera, S. Díaz, G. Pataki, E. Roth, M. Stenseke, R. T. Watson, E. B. Dessane, M. Islar, E. Kelemen, et al. (2017) Current Opinion in Environmental Sustainability, 26-27, 7-16.

Payne, A. F., Storbacka, K., Frow, P. (2008). Managing the co-creation of value. Journal of the Academy of Marketing Science, 36, 83-96.

Peterson, M. J., Hall, D. M., Feldpausch-Parker, A. M., Peterson, T. R. (2010). Obscuring ecosystem function with application of the ecosystem services concept: Essay. Conservation Biology, 24, 113119.

Peppard, J., Rylander, A. (2006). From value chain to value network:: Insights for mobile operators. European Management Journal, 24(2), 128-141.

Pingoud, K., Pohjola, J., Valsta, L. (2010) Assessing the integrated climatic impacts of forestry and wood products. Silva Fennica, 44(1), 155175. 
Polasky, S., Segerson, K. (2009). Integrating ecology and economics in the study of ecosystem services: some lessons learned. Annual Review of Resource Economics, 1, 40934.

Potschin-Young, M., Czùcz, B., Liquete, C., Maes, J., Rusch, G.M., et al. (2017). Intermediate ecosystem services: An empty concept? Ecosystem Services, 27, 124126.

Potschin-Young, M., Haines-Young, R., Görg, C., Heink, U., Jax, K., et al. (2016). Understanding the role of conceptual frameworks: Reading the ecosystem service cascade. Ecosystem Services. doi:10.1016/j.ecoser.2017.05.015

Potschin, M.B., Primmer, E., Furman, E., Haines-Young, R.H. (2016). Have ecosystem services been oversold? A response to Silvertown. Trends in Ecology and Evolution, 31(5), 334-335.

Primmer, E., Jokinen, P., Blicharska, M., Barton, D.N., Bugter, R., et al. (2015). Governance of Ecosystem Services: A framework for empirical analysis. Ecosystem Services, 16, 158166.

Ramirez, R. (1999). Value co-production: intellectual origins and implications for practice and research. Strategic Management Journal, 20, 49-65.

Renard, D., Rhemtull, J. M.,Bennett, E. M. (2015). Historical dynamics in ecosystem service bundles. Proceedings of the National Academy of the Sciences, U.S.A., 112, 1341113416.

-analysis of greenhouse gas displacement factors of wood product substitution. Environmental Science and Policy, 13 (2), 104-114.

Sandbrook, C.G., Fisher, J.A., Vira, B. (2013). What do conservationists think about markets? Geoforum, $50,232240$.

Schröter, M., Stumpf, K.H., Loos, J., van Oudenhoven, A.P.E., Böhnke-Henrichs, A., et al. (2017). Refocusing ecosystem services towards sustainability. Ecosystem Services, 25, 3543.

Silvertown, J. (2015). Have ecosystem services been oversold? Trends in Ecology and Evolution, 30(11), 641-648.

Smith, A. Cannan, E. (2000). The wealth of nations. Modern Library, New York.

Smith, A.C., Harrison, P.A., Pérez Soba, M., Archaux, F., Blicharska, M., et al. (2017). How natural capital delivers ecosystem services: A typology derived from a systematic review. Ecosystem Services, 26, 111-126.

Spangenberg, J.H., von Haaren, C., Settele, J. (2014). The ecosystem service cascade: Further developing the metaphor. Integrating societal processes to accommodate social processes and planning, and the case of bioenergy. Ecological Economics, 104, 2232.

Spash, C.L. (2015). Bulldozing biodiversity: The economics of offsets and trading-in Nature. Biological Conservation, 192, 541551.

Spohrer, J., Maglio, P. P., Bailey, J., Gruhl, D. (2007). Steps toward a science of service systems. Computer, 40, 71-77.

Spohrer, J., Vargo, S. L., Caswell, N., Maglio, P. P. (2008). The service system is the basic abstraction of service science. In Proceedings of the $41^{\text {st }}$ Annual Hawaii International Conference on System Science, Hawaii, U.S.A., January, p. 104. 
Storbacka, K., Lehtinen, J. R. (2001). Customer relationship management: Creating competitive advantage through win-win relationship strategies. McGraw Hill, Singapore.

TEEB. (2010). The Economics of Ecosystems and Biodiversity Ecological and Economic Foundations. Earthscan, London.

TEEB. (2012). The Economics of Ecosystems and Biodiversity in Business and Enterprise. Earthscan, London.

van den Belt, M., Stevens, S.M. (2016). Transformative agenda, or lost in the translation? A review of topcited articles in the first four years of Ecosystem Services. Ecosystem Services, 22, 6072.

Vargo, S. L., Lusch, R. F. (2004). Evolving to a new dominant logic for marketing. Journal of Marketing, $68,1-17$.

Vargo, S. L., Morgan, F. W. (2005). Services in society and academic thought: an historical analysis. Journal of Macromarketing, 25(1), 42-53.

Vargo, S. L., Lusch, R. F. (2006). Service-dominant logic: What it is, what it is not, what it might be. In Lusch, R.F., Vargo, S.L. (Ed.), The Service-Dominant Logic of Marketing: Dialog, Debate and Directions, (pp. 43-56). M. E. Sharpe Inc., Armonk, New York, U.S.A.

Vargo, S. L., Maglio, P. P., Akaka, M. A. (2008). On value and value co-creation: A service systems and service logic perspective. European Management Journal, 26, 145-152.

Journal of the Academy of Marketing Science, 36, 25-

38.

Vargo, S. L., (2009). Toward a transcending conceptualization of relationship: A service-dominant perspective. Journal of Business and Industrial Marketing, 24(5-6), 373-379.

Industrial Marketing Management, 40(2), 181187.

erspective of the market.

Vargo, S.L., Lusch, R.F. (2017). Service-dominant logic 2025. International Journal of Research in Marketing, 34(1), 46-67.

Waage, S., Kester, C. (2014). Private Sector Engagement with Ecosystem Services: March 2014 UPDATE. BSR.

Wallace, K.J. (2007). Classification of ecosystem services: Problems and solutions. Biological Conservation, 139(3-4), 235-246.

Wallace, K.J., Jago, M. (2017). Category mistakes: A barrier to effective environmental management. Journal of Environmental Management, 199, 1320.

Zeithaml, V. A., Rust, R. T., Lemon, K. N. (2001). The customer pyramid: creating and serving profitable customers. California Management Review, 43(4), 118. 